GRUBA T. L. The problem of forming a linguistic personality as an interdisciplinary concept.

Based on the analysis of special literature on psychology, linguistics, linguodidactics, this article presents the main problems that are developed by researchers of the linguistic personality, the "linguistic personality" definition is given, three aspects are described: anthropocentric, sociocentric, disciplinary. Special attention is paid to linguistic and linguodidactic research. As a result of the analysis and synthesis of the semantic content of "linguistic personality", the complexity and heterogeneity of this formation and its dynamics are determined, since the linguistic personality is in constant development under the influence of socio-cultural conditions and circumstances. It is proved that the aspects of the linguistic personality distinguished by scholars are interrelated, because they go beyond the limits of a certain scientific field, interact, complement each other, become the basis for new ones and emerge under the influence of different conditions, as well as the essential characteristics of the linguistic personality.

In modern sociocultural realities, the relevance of the formation of a nationally conscious linguistic personality, which is able to take responsibility for the fate of the native language, for your speech act, is growing. Recent studies prove the inextricability between the linguistic personality, linguistic mentality and national character, since deep layers of national self-consciousness and the cultural identity of the people are encoded in the language. So, cultural continuity, as a way of communication between the generations of a given people, is possible only through language. All other forms of continuity (material culture with all its diversity, varieties of artistic creation) are secondary to language.

It focuses on the complexity of the "linguistic personality" concept in its broad context (language knowledge, language skills, the desire of researchers to distinguish a number of individual competencies, etc.).

Keywords: linguistic per sonality, anthropocentric aspect, sociocentric aspect, disciplinary aspect.

DOI: https://doi.org/10.31392/NZ-npu-142.2019.08

УДК 373.5.07:336.2

Дарманська I. М.

\title{
МЕТОДИ ТА ПРИЙОМИ ФОРМУВАННЯ УПРАВЛІНСЬКОЇ КОМПЕТЕНТНОСТІ МАЙБУТНІХ КЕРІВНИКІВ ЗАКЛАДІВ ЗАГАЛЬНОЇ СЕРЕДНЬОЇ ОСВІТИ
}

У статті проаналізовано зміст практичних методів $i$ прийомів, які доиільно використовувати під час підготовки слухачів другого (магістерського) рівня вищої освіти зі спеиіальності 073 "Менеджмент". Визначено оптимальні методи та прийоми, застосування яких вплине на сформованість управлінської компетентності майбутніх керівників закладів загальної середньої освіти. Описано складові управлінської компетентності, а також практичні методи та прийоми, щзо підсилюють їх сформованість: етична (метод лекції, емоційного стимулювання, проблемної ситуації, бесіди); комунікативна (лекиї, навчальної дискусї, практики через дію, ігрові); здоров'язберігаюча (лекиії, проблемно-пошукові, аналітичні); саморозвитку та самоосвіти (лекції, самостійна робота, пояснення, дослідницькі, частково-пошукові); продуктивної діяльності (проблемні лекиії, аналітичні, діагностики); конфліктологічна (лекиії, тренінги, дискусійні, моделювання); психологічна (лекції, пояснювально-мотивуючі, конструювання (моделювання)); загальногалузева (лекції, аналітикопошуковий, моделювання); економічна (лекиії, наочно-демонстраційні, взаємодії); правова (лекиії, проблемні, пояснювально-демонстраційні); предметно-методична (лекиії, самостійні 
дослідження, інформаційно-наочний); діагностична (лекції, аналітичні, експертні); навчальна (лекциї, наочні, проектні, досліднищькі); інформаційна (лекиїі, практичні, частково-пошукові); технічна (лекиії, інструктаж, практичні).

Уміле поєднання практичних методів і прийомів навчання у формуванні управлінської компетентності майбутніх керівників закладів загальної середньої освіти вплине на якість організації освітнього процесу, рівень засвоєння змісту компетентностей, рівень мотиваиії слухачів магістратури, рівень оволодіння практичними уміннями $i$ навичками, здатність реалізовувати управлінську компетентність.

Ключові слова: майбутній керівник, підготовка, компетентнісний підхід, управлінська компетентність, складові управлінської компетентності, практичні методи та прийоми.

Формування управлінської компетентності майбутніх керівників закладів загальної середньої освіти відбувається впродовж становлення всієї професійної кар'єри директора школи, охоплюючи періоди як навчальної, так і практичної управлінської діяльності. Навчальний період реалізовується через взаємообумовлений зв'язок слухачів магістратури та науково-педагогічних працівників, що обслуговують спеціальність 073 "Менеджмент". Зазначена взаємодія буде мати позитивний результат за умови впровадження практичних методів навчання, що більш якісно реалізовуються через систему практичних прийомів формування управлінської компетентності, де засоби навчання відіграють допоміжну роль, оскільки виступають об'єктами технічного забезпечення реалізації процесу формування управлінської компетентності майбутніх керівників закладів загальної середньої освіти. Таким чином, практичні методи формування управлінської компетентності розглядаємо у єдності з прийомами та засобами.

Методи навчання, які доцільно використовувати у закладах вищої освіти, досліджували науковці: Д. Долбнєва, М. Дяченко-Богун, М. Камедія, І. Козинець, А. Кух, О. Кух, О. Лаврентьєва, О. Малихін, Г. Матукова, І. Павленко, М. Ступак та ін.

Mema cmammi - проаналізувати зміст практичних методів і прийомів, які доцільно використовувати при формуванні управлінської компетентності майбутніх керівників закладів загальної середньої освіти.

Проаналізувавши підходи науковців до трактування поняття "методи навчання" ми можемо констатувати єдність думок щодо ролі слухача магістратури та науково-педагогічних працівників у їх реалізації. Так, методи навчання розглядаються у взаємодії зазначених учасників освітнього процесу, яким має бути притаманний активний характер, що породжує зацікавленість, мотивацію, самостійність, творчість, дослідження, розуміння, аналітичні дії, індивідуальність, ініціативність.

Так, О. Малихін, Г. І. Матукова, О. Лаврентьєва, І. Павленко до основних методів навчання у вищій школі відносять лекцію, що має спонукати студентів до активних самостійних досліджень [6, с. 72-93]; М. Дяченко-Богун і І. Козинець надають перевагу активним методам навчання у виші, таким як: метод проектів, моделювання професійних ситуацій, рольові ігри, ділові ігри, круглі столи [2], візуалізована лекція, дискусія, тренінг, інтерактивні ігри, метод "мозковий штурм", метод "ток-шоу", метод “снігова куля", моделювання профресійної діяльності [4]; М. Ступак наголошує на доцільності креативних методів навчання (метод придумування, метод “якби...", метод морфологічного 
аналізу, метод інверсії) [7]; М. Камедія акцентує увагу на необхідності впровадження електронного навчання (e-learning, m-learning, u-learning, flearning, blended-learning) [3]; Д. Долбнєва, А. Кух, О. Кух наголошують на необхідності використання інтерактивних методів навчання (робота в парах, робота в малих групах, естафета, аукціон, акваріум, мікрофон, робота 3 електронними посібниками, моделювання, ажурна пилка, мозковий штурм, метод ПРЕС, два-чотири всі разом, дискусія в стилі ток-шоу, дебати, діагностика проблеми, карусель, навчаючи-навчаю, дерево рішень, кейс-метод, ділова гра, інтелектуальні тренінги, презентація [1]; круглий стіл, дискусія, метод аналізу конкретних ситуацій, метод "кейс-стаді", метод "інциденту", розбір ділової кореспонденції як “баскет-метод" [5].

Здійснений нами аналіз показав різноплановість підходів до використання методів у підготовці студентів вишів, що вказує на актуальність і доцільність їх упровадження.

Практичні методи формування управлінської компетентності майбутніх керівників закладів загальної середньої освіти ми розуміємо як сукупність способів взаємодії слухачів магістратури із науково-педагогічними працівниками, практикуючими керівниками шкіл, що сприяють якісній організації освітнього процесу, практичній підготовці студентів, їх мотивації, самоосвіті та самоконтролю.

Враховуючи необхідність засвоєння слухачами магістратури сукупності компетентностей, що утворюють управлінську, при підготовці майбутніх керівників закладів загальної середньої освіти доцільно використовувати широкий спектр методів, враховуючи: компетентність, якою має оволодіти слухач магістратури; навчальну дисципліну, що передбачає оволодіння відповідними компетентностями; зміст освітнього матеріалу, спрямованого на оволодіння відповідною компетентністю; доцільність використання конкретного методу; дієвість використання конкретного методу; спроможність реалізації методу навчання.

Розглянемо методи, що доцільно використовувати при фрормуванні компетентностей, що утворюють управлінську:

1. Етична компетентність передбачає засвоєння як теоретичної, так i практичної інформації, тому методи навчання мають формувати власний досвід емоційно-ціннісного ставлення до учасників освітнього процесу, а також спрямовуватися як на засвоєння лекційного матеріалу, так і на організацію взаємодії слухачів магістратури через спілкування, обмін інформацією.

Метод лекції доречний при засвоєнні профессійно-етичних навичок особистісної поведінки управлінця та встановлення етичних правил взаємовідносин учасників освітнього процесу; метод емоційного стимулювання формує потреби у формуванні власних ціннісних орієнтацій як слухача магістратури та і майбутніх керівників закладів загальної середньої освіти; метод проблемної ситуації спонукає до формування здатності щодо власних міркувань і висловлювань із дотриманням етичних правил у випадках виникнення відповідних дискусійних ситуацій; метод бесіди допомагає налаштувати взаємозв'язок між слухачами магістратури та науковопедагогічними працівниками, створюючи умови набуття особистісного досвіду формування етичної культури. 
2. Комунікативна компетентність передбачає не тільки уміння міжособистісного спілкування, а й навички ділового представницького спілкування, тому методи навчання мають спрямовуватися на оволодіння теоретичними засадами комунікації та практичними уміннями, навичками, досвідом їх реалізації у закладі загальної середньої освіти.

Метод лекції дає змогу засвоїти слухачам магістратури теоретичний матеріал, що характеризує комунікативні навички з позиції інтелектуальної здатності налагодження комунікативних відносин; метод навчальної дискусії спрямовується на оволодіння навичками зворотного взаємозв'язку між учасниками освітнього процесу, обміну інформацією; метод практики через дію реалізовується під час проходження слухачами магістратури практичної підготовки та формує бачення ділової комунікації, організацію комунікативної взаємодії із представниками освітніх установ, інших організацій; ігрові методи формують практичні навички налагодження суб'єкт-суб'єктних відносин у педагогічному колективі, комунікативної організації учасників освітнього процесу.

3. Здоров'язберігаюча компетентність передбачає оволодіння лекційним теоретичним матеріалом із питань організації охорони праці в закладі загальної середньої освіти, а також практичними навичками створення безпечних і нешкідливих умов для учасників освітнього процесу, тому методи навчання мають передбачати моделювання проблемних ситуацій, що потребують прийняття аналітичних рішень.

Метод лекції спрямовується на засвоєння теоретичної інформації щодо організації здоров'язберігаючої освіти як учнів, так і педагогічних працівників, обслуговуючого персоналу, а також організації виховних заходів здоров'язберігаючого характеру, спрямованих на формування мотивацій самозбереження; проблемно-пошукові методи спонукають слухачів магістратури усвідомити цінність здоров'язберігаючої освіти та виховання через формування особистої здоров'язберізаючої культури та учасників освітнього процесу; аналітичні методи фрормують знання та навички прогнозування можливих небезпечних ситуацій у закладі загальної середньої освіти, а також проектування у цих ситуаціях власної поведінки, поведінки інших учасників освітнього процесу, обслуговуючих працівників.

4. Компетентність саморозвитку та самоосвіти передбачає не тільки самостійне засвоєння теоретичного матеріалу, а й особистісне самоусвідомлення через фрормування управлінського досвіду. Тому методи навчання при формуванні компетентності саморозвитку та самоосвіти мають спрямовуватися на формування мотиваційної зацікавленості в оволодінні управлінською компетентністю.

Метод самостійної роботи $\epsilon$ основоположним у фрормуванні компетентності саморозвитку та самоосвіти, оскільки спонукає до фрормування мотиваційної потреби у власному постійному професійному зростанні, самовдосконаленні та самореалізації, зокрема на посаді керівника закладу загальної середньої освіти; метод пояснення спрямовується на формування ціннісного самоусвідомлення необхідності саморозвитку та самоосвіти впродовж професійної кар'єри; дослідницькі методи реалізовуються у процесах самопізнання наукових, педагогічних явищ, виокремлення власної позиції при 
здійсненні самостійних досліджень, написанні наукових робіт; частковопошукові методи спрямовують дії слухачів магістратури на самостійне опрацювання інформаційних потоків, що $€$ підтвердженням (запереченням) позиції науково-педагогічних працівників вишу.

5. Компетентність продуктивної діяльності передбачає розвиток стратегічного мислення у слухачів магістратури, тому методи навчання мають носити розвиваючий, логіко-стимулюючий характер, що у подальшій професійній управлінській діяльності допоможе керівнику приймати рішення стратегічного та інноваційного спрямування.

При формуванні компетентності продуктивної діяльності доцільно використовувати метод проблемної лекції, оскільки слухачі магістратури на основі отриманих знань на рівні бакалавра щодо структури, напрямів функціонування закладу загальної середньої освіти, мають отримати інформацію щодо правових, політичних, економічних, соціальних проблем, що виникають в умовах сьогодення та відображаються у практиці діяльності шкіл; аналітичні методи спонукають слухачів магістратури до мисленнєвих процесів, що дадуть можливість встановити певні взаємозв'язки між сучасними вимогами держави (суспільства) та практикою функціонування закладу загальної середньої освіти, визначити пріоритетні напрями вдосконалення й інноваційного розвитку школи; методи діагностики проблем дозволять сорормувати у слухачів магістратури уміння діагностувати учасників освітнього процесу за напрямами функціонування школи та визначати стратегічні критерії розвитку закладу загальної середньої освіти.

6. Конфліктологічна компетентність передбачає наявність як теоретичних знань, так і практичних умінь підтримання емоційно стабільного середовища та усунення конфліктогенності в межах закладу загальної середньої освіти, тому методи навчання мають вплинути на сформованість у слухачів магістратури відповідних умінь управління конфрліктними ситуаціями.

Метод лекції при фоормванні конфліктологічної компетентності допоможе зосередити увагу слухачів магістратури на необхідності засвоєння не тільки теоретичного матеріалу, а й умотивує їх до необхідності сформованості інших компетентностей, що можуть мати місце в організації та управлінні суб'єктсуб'єктними відносинами; метод тренінгу, наприклад, емоційної або вольової комунікативності, вплине на формування практичних умінь і навичок, побудову власної позиції у конфліктних ситуаціях на основі обговорень і доведення істини; дискусійні методи дають можливість донести власну позицію 3 тематичної проблеми, що обговорюється, налаштувати слухачів магістратури на якісне попередження конфліктів у закладі загальної середньої освіти, їх виявлення та усунення; метод моделювання допомагає створювати проблемні ситуації із діагностичним і оціночним супроводом, що сприятиме прийняттю рішення, доречного у конкретній конфрліктній події.

7. Психологічна компетентність передбачає оволодіння слухачами магістратури теоретичних знань психологічної організації закладу загальної середньої освіти, а також практичними уміннями їх реалізації, тому методи навчання мають спрямовуватися на створення умов психологічно стабільного навчання та їх перенесення у практику функціонування школи.

При формуванні психологічної компетентності метод лекції сприяє 
засвоєнню теоретичних засад психології управління закладом загальної середньої освіти із виокремленням психологічних особливостей керівника та учасників освітнього процесу; пояснювально-мотивуючі методи створюють розуміння управлінських психологічних ціннісних орієнтацій та необхідності постійного вдосконалення власного стилю управління задля організації сприятливого психологічного клімату у колективі; метод конструювання (моделювання) освітнього середовища формує практичні уміння побудови особистісної поведінки, учасників освітнього процесу, використання технік і методик корекції психологічного стану колективу, учнів в умовах функціонування закладу загальної середньої освіти.

8. Загальногалузева компетентність передбачає оволодіння слухачами магістратури знаннями щодо порядку та правил функціонування всіх структурних підрозділів закладу загальної середньої освіти, а також реалізації контрольних управлінських функцій стосовно працівників, що входять до їх складу, тому методи навчання мають спрямовувати майбутнього керівника до засвоєння теоретичної інформації та створювати умови практичної обізнаності у реалізації документообігу щодо функціонування закладу освіти як освітньої одиниці, щодо їх окремих структурних одиниць або учасників освітнього процесу.

При формуванні загальногалузевої компетентності метод лекції відіграє першочергову роль, оскільки сприяє оволодінню слухачами магістратури теоретичними знаннями щодо управління структурними підрозділами закладу загальної середньої освіти та оформлення відповідної документації; аналітикопошуковий метод сприяє фрормуванню умінь виокремлення недоліків у процесах ффункціонування закладу загальної середньої освіти, здійснення їх аналізу та визначенню перспективних планів удосконалення об'єкта (предмета), що досліджується; метод моделювання сприяє розгляду закладу загальної середньої освіти слухачами магістратури через технологічний процес, із виокремленням усіх його складових, що вплинуть на ефективність функціонування школи.

9. Економічна компетентність передбачає сфрормованість економічного мислення, економічних знань, що необхідні керівнику закладу загальної середньої освіти для здійснення контрольних функцій у системі економічнофінансового забезпечення закладу загальної середньої освіти загалом та окремих учасників освітнього процесу, тому методи навчання мають забезпечувати оволодіння слухачами магістратури як теоретичними, так i практичними знаннями, уміннями, навичками.

Метод лекцій має сприяти фрормуванню у слухачів магістратури цілісного уявлення про організацію фрінансової діяльності закладу загальної середньої освіти та специфіку ведення бухгалтерського обліку в ньому; наочнодемонстраційні методи доцільно використовувати під час засвоєння технології розпорядження майном закладу загальної середньої освіти, визначення кошторису, формування її доходної і видаткової частин; метод взаємодії має місце у фрормуванні практичних умінь і навичок слухачів магістратури, оскільки передбачає обмін досвідом із працівниками бухгалтерії щодо визначення штатного розпису, оплати праці та інших встановлених законом виплат педагогічним працівникам. 
10. Правова компетентність передбачає сорормованість у слухачів магістратури правової свідомості, правових знань, умінь, навичок, якими необхідно керуватися при реалізації управлінських функцій, тому методи навчання мають сприяти засвоєнню не тільки норм законодавчих і підзаконних нормативно-правових актів, а й формуванню практичного досвіду їх реалізації в управлінській діяльності та функціонуванні закладу загальної середньої освіти як невід'ємної частини правового поля держави.

Метод лекції у формуванні правової компетентності майбутніх керівників закладів загальної середньої освіти сприяє оволодінню слухачами магістратури теоретичною інформацією, що базується на законодавчій базі та має місце у правовому регулюванні праці педагогічних працівників, участі у цьому процесі директора школи, а також організації правового режиму закладу загальної середньої освіти; проблемні методи сприяють фрормуванню правової обізнаності у дослідженнях практичних випадків розв'язання індивідуальних (колективних) трудових спорів, притягнення винних осіб до відповідальності; пояснювально-демонстраційні методи підсилюють теоретичний лекційний матеріал, оскільки можуть використовуватися при засвоєнні всіх складових правової компетентності, що потребують практичного супроводу та розгляду документації, необхідної при оформленні будь-яких правових ситуацій (випадків) у закладі загальної середньої освіти.

11. Предметно-методична компетентність передбачає обізнаність директора школи не тільки в питаннях організації методичної роботи в закладі загальної середньої освіти, а й власну обізнаність у змісті навчання учнів закладу загальної середньої освіти задля якісної реалізації управлінських контрольних функцій, тому методи навчання повинні сприяти формуванню як практичної, так і теоретичної обізнаності у зазначених процесах.

За допомогою методу лекції у слухачів магістратури фрормуються знання щодо організації освітнього процесу в закладі загальної середньої освіти та участі в ньому як учасників освітнього процесу, так і керівника закладу загальної середньої освіти; метод самостійного дослідження сприяє самовдосконаленню слухачів магістратури з позиції власного педагогічного зростання, що потребує постійного дослідження інноваційних процесів розвитку освітньої системи України; інформаційно-наочний метод має реалізовуватися при оволодінні інформацією слухачами магістратури щодо атестації, підвищення кваліфікації, методичного забезпечення викладання навчальних дисциплін у закладі загальної середньої освіти.

12. Діагностична компетентність передбачає оволодіння майбутніми керівниками закладу загальної середньої освіти теоретичними та практичними знаннями, уміннями, навичками застосування технологій оцінювання стану функціонування закладу загальної середньої освіти загалом, його окремих структурних підрозділів і учасників освітнього процесу, тому методи навчання мають спрямовуватися на засвоєння слухачами магістратури не тільки теоретичної складової діагностичної і моніторингової діяльності, а й методик (технік) їх застосування у практиці фрункціонування закладу загальної середньої освіти.

Метод лекції при фрормуванні діагностичної компетентності у майбутніх керівників закладів загальної середньої освіти сприяє розумінню понять 
"педагогічний моніторинг" і “педагогічна діагностика", системи їх реалізації в межах закладу загальної середньої освіти; аналітичні методи зобов'язують слухачів магістратури прогнозувати, аналізувати, оцінювати та обґрунтовувати стани об'єктів, що досліджуються; експертні методи сприяють виокремленню негативних і позитивних тенденцій діагностичних і моніторингових досліджень із визначенням стратегічних напрямів покращення відповідних результатів, здійсненням їх експертно-аналітичного оцінювання; практичні методи створюють умови для реалізації та здійснення самостійних досліджень слухачами магістратури, формуючи уміння й навички практичної, приближеної до реальності, діагностичної і моніторингової діяльності.

13. Навчальна компетентність передбачає оволодіння слухачами магістратури теорією та практикою організації освітнього процесу в закладі загальної середньої освіти через формування контингенту, прийняття та нормативне оформлення управлінських рішень, а також реалізацію контрольно-управлінських функцій за програмним забезпеченням освітнього процесу, тому методи навчання мають сприяти оволодінню як теоретичних знань, так і практичних умінь створення внутрішньої нормативної системи забезпечення реалізації освітньої діяльності.

Метод лекції сприяє реалізації наступності у фрормуванні навчальної компетентності майбутніх керівників закладів загальної середньої освіти, оскільки сприяє фрормуванню теоретичних знань щодо змісту навчання учнів школи; наочні методи допомагають оволодіти навичками структуризації та зовнішнього оформлення навчального плану підготовки учнів закладу загальної середньої освіти та програм навчальних дисциплін; проектні методи сприяють формуванню практичних навичок проектування структурно-логічної схеми освітньої підготовки учнів закладу загальної середньої освіти; дослідницькі методи спонукають слухачів магістратури до самостійного ознайомлення із програмним забезпеченням низки навчальних дисциплін, що мають місце в закладі загальної середньої освіти.

14. Інформаційна компетентність передбачає орієнтацію майбутніх керівників закладів загальної середньої освіти в інформаційному середовищі школи та інформаційній насиченості управлінської діяльності директора, тому методи навчання повинні спрямовуватися на формування теоретичної та практичної обізнаності у питаннях отримання, обробки та перетворення інформації.

Метод лекції у фрормуванні інформаційної компетентності майбутніх керівників закладів загальної середньої освіти $€$ допоміжним методом реалізації наступності у процесі оволодіння слухачами магістратури комп'ютерною грамотністю та новітніми інформаційними технологіями, що дасть змогу директору школи вільно орієнтуватися у процесах, пов'язаних із роботою 3 інформаційними потоками та створити якісне інформаційне середовище закладу загальної середньої освіти; частково-пошукові методи сприяють оволодінню навичками роботи із Інтернет джерелами, що є вагомими в організації функціонування закладу загальної середньої освіти.

15. Технічна компетентність передбачає оволодіння слухачами магістратури теоретичними знаннями щодо реалізації управлінських функцій в сорері внутрішнього та зовнішнього обслуговування закладу загальної 
середньої освіти та практичними уміннями і навичками організації безпечного середовища для учасників освітнього процесу, тому методи навчання мають спрямовуватися на формування здатності забезпечення безпечних умов праці в межах закладу загальної середньої освіти.

Метод лекції сприяє теоретичному ознайомленню слухачів магістратури із організацією системи технічного забезпечення функціонування закладу загальної середньої освіти, роботою його структурних технічних підрозділів і розподілом функціональних повноважень осіб, що за штатним розписом до них належать; метод інструктажу сприяє фрормуванню практичних умінь і навичок організації, реалізації та контролю за проведенням інструктажів усіх видів із учасниками освітнього процесу; практичні методи сприяють оволодінню навичками реагування в екстрених ситуаціях, що потребують евакуації чи прийняття інших управлінських рішень, адекватних до кожного випадку.

Висновки. Таким чином, уміле поєднання практичних методів і прийомів навчання у формуванні управлінської компетентності майбутніх керівників закладів загальної середньої освіти вплине на якість організації освітнього процесу, рівень засвоєння змісту компетентностей, рівень мотивації слухачів магістратури, рівень оволодіння практичними уміннями і навичками, здатність реалізовувати управлінську компетентність.

Перспективи подальших досліджень полягають у застосування практичних методів і прийомів із метою підвищення рівня управлінської компетентності керівників закладів загальної середньої освіти, а також у системі їх підготовки.

\section{Використана література:}

1. Долбнєва Д. В. Інтерактивні методи навчання: сутність, необхідність та використання при підготовці фахівців 3 обліку та аудиту у BH3 України. URL : http://nltu.edu.ua/nv/A rchive/2014/24_1/389_Dol.pdf (дата звернення: 29.12.2018).

2. Дяченко-Богун М. Активні методи навчання у вищому навчальному закладі. URL : http://dspace.pnpu.edu.ua/bitstream/123456789/4444/1/D jachenko.pdf (дата звернення: 29.12.2018).

3. Камедія M. Ю. Інноваційні форми і методи навчання у BH3. URL : http://ito.vspu.net/metod_seminar/1516/innov_formy_i_metody_navch_u_vnz_bez_nomera.pdf (дата звернення: 29.12.2018).

4. Козинець I. I. Застосування активних форм і методів навчання під час вивчення української мови за професійним спрямуванням. URL: https://www.narodnaosvita.kiev.ua/?page_id=2676 (дата звернення: 29.12.2018).

5. Кух О. М., Кух А. М. Інтерактивні методи навчання фізики у BH3. URL : file:///C:/U sers/F eron/D ownloads/69586-144723-1-SM .pdf (дата звернення: 29.12.2018).

6. Методика викладання у вищій школі : навчальний посібник / О. В. Малихін, І. Г. Павленко, О. О. Лаврентьєва, Г. І. Матукова. Сімферополь : Дайфі, 2011. 270 с.

7. Ступак М. Г. Креативні методи навчання іноземних мов у BH3. URL : http://intkonf.org/stupak-mgkreativni-metodi-navchannya-inozemnih-mov-u-vnz/ (дата звернення: 29.12.2018).

\section{References:}

[1] Dolbnieva, D. V . Interaktyvni metody navchannia: sutnist, neobkhidnist ta vykorystannia pry pidhotovtsi fakhivtsiv z obliku ta audytu u V NZ Ukrainy [Interactive Methods of Learning: Essence, Necessity and Use when Training Specialists on Accounting and Audit in Ukrainian Universities]. URL : http://nltu.edu.ua/nv/A rchive/2014/24_1/389_Dol.pdf (data zvernennia: 29.12.2018). [in U krainian]

[2] Diachenko-B ohun, $M$. A ktyvni metody navchannia u vyshchomu navchal nomu zakladi [A ctive M ethods of Teaching in Higher Educational Institution]. URL : http://dspace.pnpu.edu.ua/bitstream/123456789/ 4444/1/D jachenko.pdf (data zvernennia: 29.12.2018). [in U krainian] 
[3] Kamediya, M. Y u. Innovatsiini formy i metody navchannia u V NZ [Innovative Forms and M ethods of Teaching in Higher Educational Institution]. URL: http://ito.vspu.net/metod seminar/1516/innov_formy_i_metody_navch_u_vnz_bez_nomera.pdf (data zvernennia: 29.12.2018). [in U krainian]

[4] Kozynets', I. I. Zastosuvannia aktyvnykh form i metodiv navchannia pid chas vyvchennia ukrainskoi movy za profesiinym spryamuvanniam [U se of A ctive Forms and M ethods of Teaching in the Course of Studv Ukrainian Lanquaqe of Professional Direction]. URL: https://www.narodnaosvita.kiev.ua/?page id=2676 (data zvernennia: 29.12.2018). [in U krainian]

[5] Kukh, O. M., Kukh, A.M. Interaktyvni metody navchannia fizyky u VNZ [Interactive Methods of Teaching Physics in Higher Educational Institutions]. URL: file:///C:/U sers/Feron/D ownloads/69586144723-1-SM .pdf (data zvernennya: 29.12.2018). [in U krainian]

[6] M etodyka vykladannia u vyshchii shkoli: navchalnyi posibnyk [M ethods of Teaching in High School: Manual] / O. V. M alykhin, I. H. Pavlenko, O . O. Lavrentieva, H. I. M atukova. Simferopol : Daifi, 2011. 270 s. [in Ukrainian]

[7] Stupak, M.H. Kreatyvni metody navchannya inozemnykh mov u VNZ [Creative Methods of Teaching Foreign Languages in Higher Educational Institution]. URL: http://intkonf.org/stupak-mg-kreativnimetodi-navchannya-inozemnih-mov-u-vnz/ (data zvernennia: 29.12.2018). [in U krainian]

\section{ДАРМАНСКАЯ И. Н. Методы и приемы формирования управленческой компетентности} будущих руководителей учреждений общего среднего образования.

В статье проанализировано содержание практических методов и приемов, которые иелесообразно использовать при подготовке слушателей второго (магистерского) уровня высшего образования по специальности 073 "Менеджмент". Определены оптимальные методы и приемы, применение которых повлияет на сформированность управленческой компетентности будущих руководителей учреждений общего среднего образования. Описаны составляющие управленческой компетентности, а также практические методы и приемы, усиливающие их сформированность: этическая (метод лекиии, эмочионального стимулирования, проблемной ситуащии, беседьи,) коммуникативная (лекиии, учебной дискуссии, практики из-за действия, игровые); здоровьесберегающая (лекиии, проблемно-поисковые, аналитические); саморазвития и самообразования (лекции, самостоятельной работь, объяснения, исследовательские, частичнопоисковые); продуктивной деятельности (проблемной лекции, аналитические, диагностики); конфликтологическая (лекции, тренинги, дискуссионные, моделирование); психологическая (лекции, объяснительно-мотивирующие, конструирования (моделирование)); общеотраслевая (лекиии, аналитико-поисковый, моделирование); экономическая (лекции, наглядно-демонстрационные, взаимодействия); правовая (лекиии, проблемньее, объяснительно-демонстрационные); предметнометодическая (лекиии, самостоятельного исследования, информационно-наглядньй); диагностическая (лекиии, аналитические, экспертные); учебная (лекиии, наглядные, проектные, исследовательские); информационная (лекиии, практические, частично-поисковые); техническая (лекиии, инструктажа, практические).

Умелое сочетание практических методов и приемов обучения в формировании управленческой компетентности будущих руководителей учреждений общего среднего образования повлияет на качество организации образовательного процесса, уровень усвоения содержсания компетенций, уровень мотивации слушателей магистратуры, уровень овладения практическими уменияли и навыками, способность реализовывать управленческую компетентность.

Ключевые слова: будущий руководитель, подготовка, компетентностный подход, управленческая компетентность, составляющие управленческой компетентности, практические методы и приемы.

DARMANSKA I. N. M ethods and ways of forming managing competence of the future managers of institutions of general secondary education.

The article analyzes the content of practical methods and ways that should be used during the preparation of students of the second (master) level of higher education on the specialty 073 "Management". The optimal methods and ways, the application of which will affect the formation of managerial competence of the future managers of institutions of general secondary education, have been 
determined. The components of managerial competence, as well as practical methods and ways that enhance their formation have been described: ethical (method of lecture, emotional stimulation, problem situation, conversation,); communicative (lectures, learning discussions, practices through action, games); health-preserving competence (lectures, problem-searching, analytical); self-development and selfeducation (lectures, independent work, explanation, research, partially-search); productive activity (problem lecture, analytical, diagnostics); conflict (lectures, training, discussion, simulation); psychological (lectures, explanatory-motivating, constructive (simulation)); general-industry (lectures, analyticalresearch, modelling); economic (lectures, visual-demonstration, interactions); legal (lectures, problem, explanatory-demonstration); subject-methodical (lectures, independent research, informational-visual); diagnostic (lectures, analytical, expert,); educational (lectures, visual, project, research); informational (lectures, practical, partially-search); technical (lectures, instructing, practical).

A skillful combination of practical teaching methods and techniques in the formation of the managerial competence of future heads of institutions of general secondary education will affect the quality of the organization of the educational process, the level of mastery of the content of competencies, the level of motivation of graduate students, the level of mastery of practical skills and abilities, and the ability to realize managerial competence.

Keywords: future manager, training, competence approach, managerial competence, components of managerial competence, practical methods and ways.

DOI: https://doi.org/10.31392/NZ-npu-142.2019.09

УДК 371.134:373

Долбишева Н. Г., Михайліченко А. Г.

\section{МЕТОДИКА ВДОСКОНАЛЕННЯ ТЕХНІЧНОЇ ПІДГОТОВКИ ЧЕРЛІДИРІВ НА ЕТАПІ ПОПЕРЕДНЬОЇ БАЗОВОЇ ПІДГОТОВКИ}

У статті представлена експериментальна методика вдосконалення технічної підготовки черлідирів, яка була впроваджена в навчально-тренувальний процес дітей 9-12 років на етапі попередньої базової підготовки. Дана методика побудована на основі теоретичних положеннь: теорії та методики спортивного тренування, системи підготовки спортсменів в техніко-естетичних видах спорту, основних закономірностей процесу навчання та вдосконалення техніки фізичних вправ у складнокоординаційних видах спорту, особливостей підготовки та змагальної діяльності у черлідингу, особливостей виконання черлідирами різних функиій в процесі змагальної композиції. А також попередніх досліджень щчодо місия та значення технічної підготовки в навчально-тренувальному прочесі юних спортсменів-черлідирів на етапі попередньої базової підготовки та вихідного рівня технічної та фізичної підготовленості спортсменок-черлідирів.

Експериментальна методика охоплює три рівня технічної підготовки, для яких було окремо визначено мету та завдання підготовки, власні засоби та методи спортивного тренування та які планувалися відповідно до структури двохщиклової річної підготовки з урахуванням поставлених завдань мезочиклу.

Спортивна підготовка з черлідингу побудована як иілорічний прочес і має певні часові проміжки для вирімення основних завдань навчально-тренувального процесу. Пріоритетною стороною черлідирів є технічна підготовка, оскільки основним критерієм оцінки виступу команди на змаганнях є якість та складність виконання технічних елементів.

Обтрунтовано методику вдосконалення технічної підготовки черлідирів 9-12 років на етапі попередньої базової підготовки. Встановлено, щуо річний цикл підготовки юних черлідирів 